Огляди літератури, оригінальні дослідження, погляд на проблему

УДК 618.2:618.11-092.9:576.31:611.018:546.81:616-099

DOI 10.11603/1811-2471.2016.v0.i4.7078

\title{
ОСОБЛИВОСТІ МОРФОМЕТРИЧНИХ ЗМІН ЯЄЧНИКІВ ЩУРІВ ЗА УМОВ ПОЄДНАНОГО ВВЕДЕННЯ АЦЕТАТУ СВИНЦЮ 3 ЦИТРАТОМ ЗАЛІЗА
}

ОІ. І. Колосова

\section{ДЗ «Дніпропетровська медична академія мОз України»}

РЕЗЮМЕ. Встановлено, що вплив низьких доз ацетату свинцю призводив до зменшення показників товщини поверхневого епітелію та білкової оболонки, зменшення кількості примордіальних фолікулів при збільшенні атретичних. При поєднаному введенні ацетату свинцю з цитратом заліза відносно групи свинцевої експозиції збільшилися показники товщини поверхневого епітелію та білкової оболонки, збільшилась кількість примордіальних фолікулів при зменшенні атретичних.

КЛЮчОВІ СЛОВА: ацетат свинцю, цитрат заліза, яєчники, фолікули.

Вступ. Очевидно, що в основі проблем, пов'язаних з погіршенням здоров'я людини, лежать не тільки медичні та соціально-економічні причини, а й збільшення техногенного забруднення довкілля. До поширених екополютантів належать сполуки важких металів, передусім свинцю, кадмію, ртуті, які застосовуються в різноманітних промислових виробництвах, i, попри очисні заходи, проникають в атмосферу, воду i ґрунт та становлять небезпеку для людини й навколишнього середовища [1-4]. Погіршення екологічної та демографічної ситуації в Україні зумовлює актуальність вивчення впливу важких металів на репродуктивне здоров'я $[5,6]$.

Актуальним аспектом сучасних наукових розробок також $\epsilon$ пошук нових біоантогоністів сполукам свинцю. Серед таких сполук увагу науковців привертає нанозалізо, яке має високу хімічну реакційну здатність, що дозволяє застосовувати цей наноматеріал для прискорення (каталізу) хімічних реакцій, зокрема в сфері очищення навколишнього середовища від забруднювачів органічного і неорганічного походження. Нанозалізо $\epsilon$ перспективним засобом для лікування залізодефіцитних станів, особливо у жінок дітородного віку, бо потреба в залізі у них удвічі вища, ніж у чоловіків, у зв'язку з регулярними втратами крові під час менструації $[7,8]$. На жаль, токсичний вплив чинників малої інтенсивності на репродуктивну систему з урахуванням їх біологічного антагонізму з мікроелементами як у природних, так і в експериментальних дослідженнях вивчений недостатньо, що зумовило напрямок нашої роботи.

Дане дослідження $\epsilon$ фрагментом міжкафедральної планової наукової теми Державного закладу Дніпропетровська медична академія «Розвиток та морфофункціональний стан органів i тканин експериментальних тварин та людини в нормі, в онтогенезі, під впливом зовнішніх чинників» (номер державної реєстрації 0111U012193).

Метою даного дослідження $\epsilon$ вивчення змін гістологічної будови яєчників самиць щурів на до- сліджуваних термінах гестації за умов ізольованого введення ацетату свинцю та його комбінації з цитратом заліза.

Матеріал і методи дослідження. Вивчення морфофункціональних змін яєчників за умов низьких доз ацетату свинцю проводили на статевозрілих щурах - самицях лінії Wistar з початковою масою 150 - 180 г, яких утримували на стандартному раціоні віварію Дніпропетровської медичної академії. В експериментальних моделях використовували розчини ацетату свинцю та цитрату заліза, отриманого за аквананотехнологією [Науково-дослідний інститут нанобіотехнологій та ресурсозбереження України, м. Київ].

Щури були поділені на 3 групи, по 24 тварини в кожній: група №1 (Д№1) - тварини, яким вводили розчин ацетату свинцю у дозі 0,05 мг/кг, група №2 (Д№2) - тварини, яким вводили розчин ацетату свинцю у дозі 0,05 мг/кг з розчином цитрату заліза у дозі 1,5 мкг/кг, група №3 - контрольна, тварини які отримували дистильовану воду. В кожній групі вагітні самки були поділені залежно від стадії, на якій планувалось вилучати плоди та яєчники для подальших досліджень, на 3 підгрупи: самки з терміном вагітності 12, 16 та 20 діб. Кількість тварин у підгрупах відбиралась за принципом мінімальності для проведення статистичної обробки цифрових показників з метою отримання достовірних результатів (8 тварин у кожній підгрупі).

Самиць щурів спарювали за стандартною схемою. 3 моменту виявлення сперматозоїдів у вагінальних мазках рахували перший день вагітності. Згідно з загальноприйнятими інструкціями проведення експериментальних робіт, розчини ацетату свинцю та цитрату заліза вводили самицям через зонд один раз на добу, в один і той же час (з 11 до 12 години). Експозиція дії хімічних чинників на самок щурів тривала з 1 по 11, 15 або 19 день вагітності, відповідно на 12, 16 або 20 добу вагітності проводили оперативний забій шляхом передозування ефірним наркозом. В період прове- 
Огляди літератури, оригінальні дослідження, погляд на проблему

дення експерименту спостерігали за загальним станом, поведінкою вагітних самиць, реєстрували динаміку маси тіла.

Після вилучення ембріонів з матки видаляли яєчники самиці, які фіксували у розчині 10 \% нейтрального формаліну з наступним виготовленням серійних парафінових гістологічних зрізів, що після депарафінування були пофарбовані гематоксиліном і еозином та за Маллорі-Слінченко. Статистичну обробку результатів дослідження здійснювали за допомогою методів варіаційної статистики з використанням Е-критерію Стьюдента.

Результати й обговорення. При гістологічному дослідженні яєчників щурів було встановлено, що структурна організація органа дослідних груп практично не відрізняється від контролю: незалежно від досліджуваних термінів гестації на поперечному зрізі у всіх гонадах чітко видно білкову оболонку, кіркову і мозкову речовини, функціональні утворення (фолікули на різних стадіях розвитку й жовті тіла) та кровоносні судини (рис. 1).

Зовні яєчник був укритий переважно одношаровим кубічним епітелієм, на апікальній поверхні якого візуалізувалися мікроворсинки з ділянками призматичного та плоского епітелію. Під поверхневим епітелієм розташовувалася білкова оболонка, що мала будову щільної сполучної тканини, в якій поміж видовжених фібробластоподібних клітин розташована густа сітка колагенових волокон.

Кіркова речовина яєчників контрольної та дослідних груп представлена сполучнотканинною основою (стромою), в якій знаходилися фолікули різного ступеня зрілості, що переважно підлягали фізіологічній атрезії, та жовті тіла. Під білковою оболонкою в кірковій речовині групами

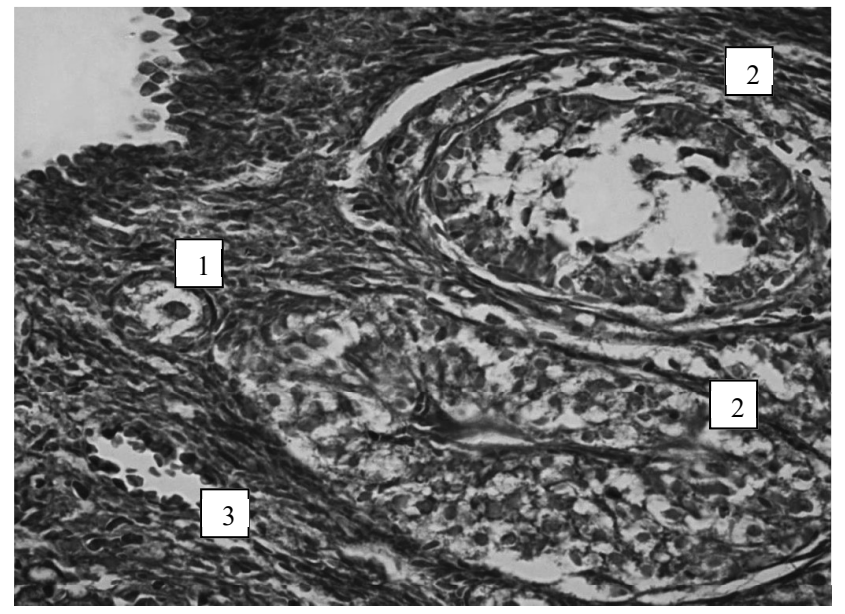

Рис. 1. Кіркова речовина яєчника щура дослідної групи №1 на 16 добу вагітності: 1 - примордіальний фолікул; 2 - фолікули, що підлягають атрезії, строма яєчника; 3 - венула. Забарвлення за МаллоріСлінченко. 36×400. Масштабний відрізок - 20 мкм. або поодиноко розташовувалися примордіальні фолікули, до їх складу входив невеликих розмірів ооцит, оточений одним шаром фолікулярних клітин (рис. 1).

Морфометричні дослідження показали, що в дослідній групі ізольованого введення ацетату свинцю, порівняно з контролем, відбувається:

1) зменшення товщини поверхневого епітелію в наступному порядку: 12 доба гестації $(-18,4 \%(p<0,01))>16$ доба $(-16,9 \%(p<0,01))>20$ доба $(-0,1 \%(p>0,05))$;

2) зменшення товщини білкової оболонки наступним чином: 16 доба гестації $(-19,2 \%(p<0,05))$ $>20$ доба гестації $(-11,0 \%(p>0,05))>12$ доба гестації $(-10,4 \%$ (p>0,05)). Наші результати узгоджуються з даними інших вчених [9], які досліджували вплив ацетату свинцю на репродуктивну систему невагітних самиць щурів.

Аналіз фолікулярного апарату яєчників показав, що в дослідній групі свинцевої експозиції, порівняно з контролем, відбувається:

1) зниження кількості примордіальних фолікулів в правих яєчниках: 16 доба $(-26,7 \%(p<0,001))$ $>12$ доба $(-23,4 \%(p<0,05))>20$ доба $(-22,8 \%$ $(p<0,01))$, а в лівих: 16 доба $(-25,5 \%(p<0,01))>20$ доба $(-23,8 \%(p<0,01))>12$ доба $(-23,6 \%(p<0,05))$;

2) збільшення кількості атретичних фолікулів в правих яєчниках у середньому в 2,8 раза $(p<0,001)$ на всіх термінах гестації, а в лівих - достовірно зменшуючись у ряду: 12 доба вагітності $(+2,9$ рази $(p<0,001))>16$ доба $(+2,7$ рази $(p<0,001))$ = 20 доба $(+2,7$ рази $(p<0,001))$.

Структурно-функціональні зміни репродуктивних органів у самок ссавців (збільшення або зменшення кількості різних типів фолікулів, посилення процесу атрезії, дозрівання фолікулів, затримка інволюції жовтих тіл і ін.) в екстремальних умовах проживання і в експериментах з вивчення дії токсичних речовин відзначаються багатьма авторами і підтверджують результати нашого експериментального дослідження [9-11].

Аналіз результатів показників поверхневих структур у дослідній групі № 2, в якій проводили поєднаного введення ацетату свинцю з цитратом заліза, показав наступні зміни, порівняно з групою з ізольованим введеннм ацетату свинцю:

1) збільшення товщини поверхневого епітелію в правих яєчниках: 16 доба гестації (+27,3 \% $(p<0,01))>12$ доба $(+26,3 \%(p<0,05))>20$ доба $(+2,7 \%(p>0,05))$, а в лівих: 12 доба гестації (+50,1\% $(p<0,01))>16$ доба $(+44,3 \%(p<0,01))>20$ доба $(+2,9 \%(p>0,05))$;

2) збільшення товщини білкової оболонки в правих яєчниках: 16 доба гестації (+41,7 \% $(p<0,001))>20$-та доба $(+18,2 \%(p>0,05))>12$ доба $(+12,7 \%(p>0,05))$, а в лівих: 16 доба гестації 
Огляди літератури, оригінальні дослідження, погляд на проблему

$(+43,2 \%(p<0,001))>20$ доба $(+20,4 \%(p<0,05))>$ 12 доба $(+13,3 \%(p>0,05))$.

Порівнюючи показники кількості фолікулів в яєчниках щурів дослідної групи комбінованого введення з групою впливу ацетату свинцю виявлено:

1) збільшення кількості примордіальних фолікулів в правих яєчниках: 12 доба $(+36,0 \%$ $(p<0,01))>16$ доба $(+33,7 \%(p<0,05))>20$ доба $(+28,7 \%(p<0,05))$, а в лівих: 12 доба $(+38,2 \%$ $(p<0,05))>16$ доба $(+33,3 \%(p<0,05))>20$ доба $(+33,1 \%(p<0,01))$;

2) зменшення кількості атретичних фолікулів приблизно у 2,7 раза $(p<0,001)$ на всіх термінах гестації, як в правих, так і в лівих яєчниках.

Порівняти отримані результати немає можливості, оскільки у світовій науковій літературі відсутні дані у цьому напрямку.

\section{ЛITEPATYPA}

1. Association of lead and cadmium exposure with frailty in US older_adults / E. García-Esquinas, A. NavasAcien, B. Pérez-Gómez // Environ Res. - 2015. - Vol. 137. -P. $424-443$.

2. Важкі метали як фактор екологічної небезпеки / [Н. М. Мельникова, І. В. Калінін, Є. А. Деркач та ін.]. Київ : Вид-во. НУБіП, 2009. - 192 с.

3. Сердюк А. М. Екологія довкілля та безпека життєдіяльності населення у промислових регіонах України / А. М. Сердюк, В. П. Стусь, В. І. Ляшенко. - Дніпропетровськ : Пороги, 2011. - 486 c.

4. Скальный А. В. Диагностика, профилактика и лечение отравлений свинцом / А. В. Скальный, А. Т. Быков, Б. В. Лимин. - М. : Защита, 2002. - 52 с.

5. Авраменко Н. В. Аспекты репродуктивного здоровья населения Украины / Н. В. Авраменко, Д. Е. Барковский // Запорож. мед. журнал. - 2010. - № 3. - С. 71-73.

6. Вылегжанина Т. А. Морфофункциональная характеристика реакции некоторых органов репродуктивной и симпато-адреналовой систем на действие ацетата свинца / Т. А. Вылегжанина, Т. Е. Кузнецова, Е. Л. Рыжковская // Ксенобиотики и живые системы: матер. III междунар. научн. конф., Минск, 22-24 октября 2008 г. - Минск : Изд. Центр БГУ, 2008. - С. 25-27.
Висновки. На підставі аналізу результатів проведених досліджень можна зробити висновок, що експозиція ацетатом свинцю $(0,05 \mathrm{Mr} / \mathrm{кг})$ призводить до порушення кількості фолікулів та зміни товщини поверхневих структур яєчника. При поєднаному введенні ацетату свинцю з цитратом заліза кількість примордіальних фолікулів більша, при меншій кількості атретичних фолікулів, відносно показників групи експозиції свинцем, що свідчить про зниження негативної дії металу на морфофункціональний стан яєчників щурів в експерименті.

Перспективи подальших досліджень. Отримані результати, на нашу думку, пов'язані із компенсаторним впливом цитрату заліза на негативну дію ацетату свинцю, що потребує подальших гістологічних та морфологічних досліджень.

7. From iron oxide nanoparticles towards advanced iron-based inorganic materials designed for biomedical applications / A. Figuerola, R. Di Corato, L. Manna, T. Pellegrino // Pharmaceutical Research. - 2010. - Vol. 62, N. 2. - P. 126-143.

8. Біобезпечні наночастинки металів в наномедицині на нанобіотехнології / 3. Р. Ульберг, Т. Г. Грузіна, С. М. Дибкова, Л. С. Рєзніченко // Вісник проблем біології та медицини. - 2010. - № 4. - С. 72-77.

9. Исследование жизнеспособности клеток при воздействии ацетата свинца на организм крысы / [Н. А. Мельникова, О. С. Шубина, Н. А. Дуденкова и др.] // Современные проблемы науки и образования. - 2013. - № 5; URL: http://www.science-education.ru/111-10588

10. Кальян В. В. Яєчниковий резерв щурів в умовах гіпокінезії помірної жорсткості / В. В. Кальян, Г. І. Губіна-Вакулик, Т. Є. Комісова // Буков. мед. вісн. - 2009. № 4. - С. 123-125.

11. Лебедева Т. С. Морфодинамика фолликулогенеза млекопитающих / Т. С. Лебедева, Ю. В. Храмова // лОМОНОСОВ - 2014 : тез. докл. XXI Междунар. конф. студентов, аспирантов и молодых ученых: Секция «Биология», Москва, 7-11 апреля 2014 г. - М. : Изд. Московского университета, 2014. - С. 7.

\section{FEATURES OF MORPHOMETRIC CHANGES IN RAT OVARIES UNDER COMBINED INJECTION OF LEAD ACETATE WITH IRON CITRATE}

\section{Dnipropetrovsk Medical Academy}

SUMMARY. It was found that the effect of low doses of lead acetate led to the reduction of thickness surface epithelium and protein shell, reducing the number of primordial follicles by increasing atretic. In the combined injection of lead acetate with iron citrate thickness of surface epithelium and protein shell, the number of primordial follicles while reducing atretic compared to group of lead exposure were increased.

KEY WORDS: lead acetate, iron citrate, ovaries, follicles. 